\title{
HOUSEHOLD DEMAND FOR VARIABLE ANNUITIES
}

\author{
Jeffrey R. Brown* \\ James M. Poterba \\ CRR WP 2004-08 \\ Released: March 2004 \\ Draft Submitted: February 2004 \\ Center for Retirement Research at Boston College \\ 550 Fulton Hall \\ 140 Commonwealth Ave. \\ Chestnut Hill, MA 02467 \\ Tel: 617-552-1762 Fax: 617-552-1750 \\ http://www.bc.edu/crr
}

* Jeffrey R. Brown is an assistant professor of finance at University of Illinois' College of Commerce and Business Administration. James M. Poterba is the Mitsui Professor of Economics at the Massachusetts Institute of Technology. The research reported herein was performed pursuant to a grant from the U.S. Social Security Administration (SSA) to the Center for Retirement Research at Boston College (CRR). The opinions and conclusions are solely those of the authors and should not be construed as representing the opinions or policy of the SSA or any agency of the Federal Government or of the CRR. We thank Amir Sufi for outstanding research assistance, and the Social Security Administration and the Boston College Center for Retirement Research for research funding. We are grateful to Moshe Milevsky, Kent Smetters and seminar participants at the 2004 American Economic Association annual meetings for helpful comments and discussions.

(C) 2004, by Jeffrey R. Brown and James M. Poterba. All rights reserved. Short sections of text, not to exceed two paragraphs, may be quoted without explicit permission provided that full credit, including (C) notice, is given to the source. 


\section{About the Center for Retirement Research}

The Center for Retirement Research at Boston College, part of a consortium that includes parallel centers at the University of Michigan and the National Bureau of Economic Research, was established in 1998 through a grant from the Social Security Administration. The goals of the Center are to promote research on retirement issues, to transmit new findings to the policy community and the public, to help train new scholars, and to broaden access to valuable data sources. Through these initiatives, the Center hopes to forge a strong link between the academic and policy communities around an issue of critical importance to the nation's future.

\section{Center for Retirement Research at Boston College}

550 Fulton Hall

140 Commonwealth Ave.

Chestnut Hill, MA 02467

phone: 617-552-1762 fax: 617-552-1750

e-mail: crr@bc.edu

http://www.bc.edu/crr

Affiliated Institutions:

American Enterprise Institute

The Brookings Institution

Massachusetts Institute of Technology

Syracuse University

Urban Institute 
The shift from defined benefit to self-directed defined contribution plans, the possibility of reforming Social Security so that it includes personal accounts, and the growth in IRAs are examples of a broad shift toward greater self-reliance in the provision of retirement income in the United States. In policy and academic discussions of individual retirement security in this new environment, two issues are particularly prominent. First, much attention has been paid to the role of equity markets, and the extent to which workers utilize equities as part of their retirement portfolios. There has been a steady rise in the extent of equity market participation over the past two decades, largely as a result of the growth of mutual funds and the expansion of self-directed retirement accounts. The second issue is the decline in life annuitization in retirement, arising primarily from the shift away from automatically annuitized DB plans and towards DC plans, such as 401(k)'s, few of which even offer annuities as a payout option.

Despite the significance of both equity ownership and annuitization, very little research has focused on the rapid growth during the 1990s of a class of products known as variable annuities, which in principle combine equity ownership and an option to annuitize. While variable annuities were first introduced by insurance companies in the mid-1950s to compete with mutual funds, the market remained quite small for several decades. In the early 1990s, however, the market began to grow rapidly. According to the American Council of Life Insurers, gross sales of individual (nongroup) variable annuity considerations rose from \$3.5 billion in 1990 to nearly \$63 billion in 1999 . Individuals may demand variable annuities for at least three, not necessarily exclusive, reasons. The first is to accumulate wealth at favorable after-tax rates of return. Interest, dividends, and capital gains that accrue on assets held in variable annuity accounts are not taxed until the policyholder receives variable annuity payouts. This provides policyholders with the tax benefits of "inside build up," just as in the case of Individual Retirement Accounts and 401(k) plans. 
Gentry and Milano (1998) study how taxes affect annuity demand. They use both cross-state variation in income tax rates and time series variation in federal rates between 1984 and 1993 to identify the key behavioral relationship. They find that aggregate sales of variable annuities are higher in states with high state marginal income tax rates than in states with low income tax rates, suggesting that variable annuities are purchased in part to avoid the tax burden on investments in traditional taxable accounts. At the time of their study, there was no household-level data on variable annuity ownership.

A second potential attraction of variable annuities is that they provide various forms of insurance, such as the common provision that if the policyholder dies before retirement, heirs receive at least the nominal value of the policy contributions. Milevsky and Posner (2001) use risk-neutral option pricing to value the guaranteed minimum death benefit in variable annuities. They conclude that a simple return-of-premium death benefit is worth between only one and ten basis points, thereby casting doubt on the extent to which these products are purchased for their accumulation period insurance features. However, we know of no study that empirically examines whether investor characteristics, such as self-reported risk aversion, can explain variable annuity demand.

The third motivation for holding variable annuities is the option to convert to a life annuity and thus provide annuitized income in retirement, with the payouts indexed to the performance of a diversified investment portfolio. Brown, Mitchell and Poterba (2001) explore this aspect of annuity demand in a stylized life-cycle model. They conclude that most consumers would find it welfare-enhancing to have at least a portion of their retirement portfolio in equity-linked annuity products, but they do not examine empirical patterns of annuity demand. Indeed, it appears that very few variable annuity products are ever converted into life annuities during retirement. 
The limited body of research on household demand for variable annuities is explained largely by the lack of data. Prior to the 1998 Survey of Consumer Finances, no national representative household survey asked a sufficiently detailed set of questions about annuity income and ownership to make it possible to identify households with variable annuity holdings. Both the 1998 and the 2001 SCF surveys now provide this information. We use these surveys to study the ownership of variable annuity products. Our analysis focuses primarily on the role of taxes, but we also consider insurance aspects of annuity demand.

This paper is divided into four sections. The first describes how variable annuities work, focusing particularly on the tax incentives, the insurance features, and payout options at retirement. It also provides data on the size of the U.S. market. Section two explains how the 1998 and 2001 SCF data can be used to analyze the cross-sectional determinants of variable annuity ownership. It presents summary statistics on our data set and on the inter-relationships between ownership of variable annuities and other assets. The third section develops an empirical model for the probability that a household owns a variable annuity. It reports our central findings and interprets them in light of our various hypotheses. There is a brief conclusion which sketches several research issues about the demand for variable annuities that our analysis raises but cannot resolve due to data limitations.

\section{The U.S. Variable Annuity Market}

Variable annuities combine features of insurance products and mutual fund-style investment accounts. The funds invested in a variable annuity are held in designated "subaccounts" that are kept separate from the insurance company's other assets. As a result, and unlike most life insurance or fixed annuity products, the assets are not subject to claims by the insurance company's creditors should the insurance company become insolvent (Weiss Ratings, 
2002). Income earned on the annuity investments is tax-deferred until the individual begins making withdrawals. The preferential tax treatment of variable annuities derives from the inclusion of some form of "life insurance" in the contract, namely, a death benefit of some minimum value. Because individuals who hold whole life insurance policies do not pay taxes on accruing income, the non-taxation of income on annuity policies preserves comparable treatment of these two asset categories.

Sales of variable annuity products in the U.S. exploded during the 1990s. Figure 1 shows that individual (non-group) annuity considerations grew from under $\$ 3.5$ billion per year in 1990, to nearly $\$ 63$ billion in 1999 , for an average annual growth rate of approximately 38 percent. $^{1}$ Group variable annuity sales grew even faster over this period, from $\$ 1.8$ billion in 1990 to $\$ 72.5$ billion in 1999.

These statistics refer to sales of new variable annuity policies, rather than the net purchases of variable annuities. In many cases the new non-qualified policy sales are the result of what is known in the industry as a "1035 exchange."” 1035 refers to a provision in the tax code that allows for the direct transfer of accumulated funds in an annuity policy to another annuity policy without creating a taxable event. If an individual sells stocks in a taxable account in order to purchase shares of a different company, this exchange would trigger capital gains taxation. With annuities, however, there is no tax consequence. An individual can exchange one company's products for another's with the earnings from the original investment still tax deferred until the money is taken out of the annuities for good. ${ }^{3}$

\footnotetext{
${ }^{1}$ All sales figures in this paragraph are taken from the ACLI Life Insurers Fact Book 2000.

${ }^{2}$ Within qualified plans, both mutual funds and variable annuities are permitted to be "exchanged between vendors" without triggering a tax liability.

${ }^{3}$ Title 26, subtitle A, chapter 1, subchapter O, Part III, Section 1035 states that "no gain or loss shall be recognized on the exchange" of one annuity policy for another. The same advantage holds true for life insurance and endowment policies. Source: http://www.annuityadvantage.com/1035exchange.htm
} 
According to an industry study by Cerulli Associates (2003), 1035 exchanges now represent the majority of sales in the industry. Indeed, according to estimated 2001 sales figures, less than 20 percent of total sales are new business to the industry. While "total sales" of variable annuities rose sharply from 1995 to 2000 , a smaller and smaller share of these sales represented net new flows into these products. ${ }^{4}$ Figure 2 shows both net flows and total sales of variable annuities for each year between 1995 and 2001. The figure shows that while net flows represented more than half of total sales between 1995 and 1997, they declined to only twenty percent of total sales at the end of the sample period. The rise in 1035 exchanges suggests that companies in the industry are fighting over the existing market to an ever-larger extent, and that sales to new customers are actually beginning to decline. ${ }^{5}$

\subsection{The Structure of Variable Annuity Products}

Variable annuities can be purchased both inside and outside of retirement plans. Qualified annuities are purchased using assets from qualified retirement plans, such as 401(k)'s. In many cases, such as university employees purchasing annuities through TIAA-CREF, qualified annuities may be purchased through an employer. We focus on annuities purchased using non-retirement plan assets, which are non-qualified annuities.

An insurance company offering annuities typically offers a broad range of sub-accounts in which the assets may be invested. Equity and bond portfolios are the most common options. A buyer may purchase the variable annuity with a single initial premium payment, or with a sequence of premium payments over time. Typically, the insurance company providing the variable annuity collects two fees: an investment management fee, and an insurance charge. The insurance charge covers a variety of insurance benefits associated with the variable annuity. Many variable

\footnotetext{
${ }^{4}$ We thank Cynthia Saccocia of Cerulli Associates for allowing us access to this proprietary study.

${ }^{5}$ Data from the Cerulli study uses a different data source than does the ACLI. As a result, the total sales figures in figures 1 and 2 are not a perfect match, although the overall trends of rapidly increasing sales are similar.
} 
annuities have front-end retail loads, and there are often surrender penalties that apply if funds are withdrawn from the variable annuity before a pre-specified time period, often seven years. These penalties, known as Contingent Deferred Surrender Charges, can be several percent of the annuity's value. Indeed, outside of TIAA-CREF and Vanguard, pure no-load variable annuities appear to be rather uncommon.

The combination of investment management expenses and insurance charges substantially reduces the returns available to variable annuity investors. In 2002, Morningstar reported that the average total expense for variable annuities investing in diversified portfolios of domestic equities with a "growth and income" focus was 115 basis points, while that for variable annuities focused on government bonds was 191 basis points. These expenses are substantially larger than those on open-end mutual funds holding similar assets.

Table 1 presents information on the average expenses and insurance costs for variable annuities by various categories. The data for this table are drawn from Morningstar databases for both variable annuities and mutual funds. The table shows that the asset-weighted average management expense for variable annuities in 2002 was 57 basis points, compared with 92 basis points for all mutual funds. The average insurance charge associated with a variable annuity was 109 basis points, however, so the total expenses equaled 165 basis points. Only 5 percent of VA contracts have insurance expenses under 75 basis points, whereas 12 percent charge more than 140 basis points.

The table shows that the management expenses vary by the variable annuity's investment objective, with the highest charges on international bond and international stock funds. For mutual funds, the funds with these investment objectives also have two of the three highest average expense ratios. There is some variation across investment objectives in the insurance charge for 
the variable annuities. Since the value of an option to repay the annuity principal, or the highest value of the annuity assets on any policy anniversary, depends on portfolio parameters such as the volatility of the underlying assets, the disparities in insurance costs are not surprising. The high insurance charge of 130 basis points per year for variable annuities invested in government bonds is puzzling, given that government bonds are a low risk investment. However, it should be noted that there is a significant amount of complexity and variation across contracts in the precise nature of the insurance features. It is possible that the insurance contracts typically associated with annuities that are invested in government bond funds are different from those associated with other asset allocations.

The management costs associated with investments in mutual funds or variable annuities can have an important effect on long-run wealth accumulation. To illustrate this, assume that an individual contributes $\$ 1000$ to an account at age 30 and allows it to grow for 30 years at an average annual nominal return of 10 percent before administrative costs. Assume that the assets are invested in a way that avoids taxation during the accumulation phase. At age 60, the value of the account will have grown to $\$ 13,563$ if the expense charge is 92 basis points per year, but to $\$ 11,400$ if the charge is 165 basis points. Thus an increase in the expense ratio equal to the difference between the average expense ratio for mutual funds and for variable annuities reduces wealth at age 60 by roughly 16 percent.

\subsection{The Tax Treatment of Variable Annuities: Accumulation and Payout Phases}

The returns to assets held in variable annuities are not taxed until the annuity holder receives a distribution from the annuity. The opportunity for assets to grow at the pre-tax rate of return, particularly for long-horizon investors, has the potential to generate higher after-tax wealth from variable annuity investments than from traditional taxable investments. The complexity in 
the tax treatment of variable annuities occurs in the withdrawal phase. If this takes place before the annuitant is $591 / 2$, unless the distribution takes the form of a life annuity, the distribution is subject to income tax on the difference between the payout and the premium, plus a 10 percent penalty tax.

There is no reliable, publicly available data on withdrawals from variable annuity accounts. The limited evidence that is available suggests that funds accumulated in variable annuity accounts, however, are rarely converted to life contingent annuities at retirement. Brown and Warshawsky (2001) report that only about one percent of the individuals covered by variable annuity products are receiving payments from these accounts - the rest are still in the accumulation phase. Many of the variable annuities currently in the accumulation phase, however, may eventually be annuitized.

There are several different ways to receive distributions from a variable annuity, and they are taxed differently. First, the policyholder could choose a lump-sum distribution. In this case the tax due at the time of the distribution is $\tau^{*}(\mathrm{~V}-\mathrm{P})$ where $\tau$ denotes the policyholder's ordinary income tax rate, $\mathrm{V}$ denotes the value of the variable annuity at the time of the distribution, and $\mathrm{P}$ denotes the variable annuity premium, which was probably paid some time ago. The premium, $\mathrm{P}$, functions just like the purchase price for an asset that is subject to capital gains tax. Note that in this case there is no annuitization associated with the variable annuity product. If the policyholder chooses to take several distributions from the policy, the distributions are fully taxable as ordinary income until the policy's remaining value falls below $\mathrm{P}$. The early payouts from the policy are assumed to be income, while the later payouts are returns of principal. 
Second, the policyholder could choose to receive a stream of variable payouts for a prespecified length of time, such as 10 years. In this case, the insurance company finds the value $\mathrm{A}_{0}$ that satisfies the equation:

$$
V=\sum_{t=1}^{T} \frac{A_{0}}{(1+R)^{t}}
$$

where $\mathrm{V}$ is the value of the accumulation, $\mathrm{R}$ is the variable annuity's "Assumed Interest Rate," as in Bodie and Pesando (1983), and $\mathrm{T}$ is the number of periods over which the annuitant chooses to receive payouts. Payouts on a variable annuity depend on the returns on the assets that underlie the annuity. A variable annuity is defined by an initial annuity payment $\mathrm{A}_{0}$, and an "updating rule" that relates the annuity payout in future periods to the previous payout and the intervening portfolio returns. If the return in each period is denoted by $\mathrm{z}_{\mathrm{t}}$, then the updating rule for the annuity payout $\mathrm{A}_{\mathrm{t}}$ is:

$$
A_{t+1}=\frac{A_{t}\left(1+z_{t}\right)}{(1+R)}
$$

With a fixed number $(\mathrm{T})$ of variable payouts, the annuitant must include in ordinary income the difference between each payout and $(\mathrm{P} / \mathrm{T})$. Thus the tax payment associated with the $\mathrm{t}^{\text {th }}$ payout from the annuity is $T A X_{t}=\tau\left(A_{t}-\frac{P}{T}\right)$.

Third, the policyholder could choose a life contingent annuity, which therefore has an unknown number of payments and uncertainty about the payout size. Brown, et al. (1999) describe the tax treatment of this case in some detail. In this case, $\mathrm{A}_{0}$ is determined implicitly from the equation

$$
V=\sum_{t=1}^{T} \frac{A_{0} \cdot S_{t}}{(1+R)^{t}}
$$

where $S_{t}$ is the probability that the individual will live to period $t$, and $T$ is chosen to represent the 
maximum number of payouts that the annuitant might receive if he or she lives to the maximum age assumed by the insurance company.

The tax treatment of life-contingent payouts is different than the treatment of payouts with a fixed number of certain payouts. For life annuities, the IRS specifies an inclusion ratio $(\lambda)$, which determines the share of annuity payments in each period that must be included in the recipient's taxable income. The inclusion ratio is designed to measure the fraction of each annuity payout that reflects the capital income on the accumulating value of the annuity premium. The inclusion ratio is calculated by finding the expected number of years over which the annuitant can expect to receive benefits. This period, T', is determined by the IRS using the 1983 Individual Annuitant (Unisex) Mortality Table and the individual annuitant's age at the time when payouts begin ${ }^{6}$. The inclusion ratio is $\lambda=1-\frac{P_{0}}{T^{\prime} \cdot A_{0}}$. Until $\mathrm{T}^{\prime}$ years after the annuity payout begins, the tax payment on each annuity payment is given by $T A X_{t}=\tau \cdot \lambda \cdot A_{t}$. After $\mathrm{T}^{\prime}$ years, all payouts from the annuity policy are considered taxable income. This tax rule causes a discrete increase in the annuitant's tax burden, often at an advanced age.

Payouts from variable annuities are taxed as ordinary income. For variable annuities that invest in corporate equities, investors are therefore giving up the opportunity to receive capital gains tax treatment on the value of their appreciating assets. The tax rate on income from corporate equities is therefore a critical determinant of the tax advantage of investing in a variable annuity. Consider a simple example of an equity index fund that earns an 8 percent return each year, net of expenses, with 2 percent from dividends and the remaining 6 percent from capital gains. Assume that the tax regime is similar to the one that applied during our sample period, and that assigned a notably higher tax rate to equity income than the current U.S.

\footnotetext{
${ }^{6}$ The 2001 tax legislation directed the IRS to update the mortality tables that is uses to compute some of the required payout rates associated with retirement distributions. This may affect the calculation of taxes on variable annuity payouts
} 
income tax does. In particular, assume that the investor is in a 33 percent marginal tax bracket for ordinary income, and that the long-term capital gains tax rate is 20 percent. Further assume that capital gains are taxed as they accrue. The annual return on this fund is therefore $6.14=$ $.67 * 2+.80 * 6$ percent.

Now imagine that the investor held the same investment in a variable annuity so that all tax on the fund's return is deferred until the assets are withdrawn. The investor benefits from tax deferral, but loses because income that was taxed at capital gains rates now becomes subject to ordinary income taxation. If the expenses on the variable annuity are the same as those of the mutual fund, then the value of a one dollar investment in the variable annuity, after $\mathrm{K}$ years, is:

$$
V(K)=e^{0.08 \cdot K}-\tau \cdot\left(e^{0.08 \cdot K}-1\right)=(1-\tau) \cdot e^{0.08 \cdot K}+\tau
$$

With $\tau=.33$, this reduces to $(.67) \cdot e^{0.08 \cdot K}+.33$. For the variable annuity to outperform the openend mutual fund we need $(.67) \cdot e^{0.08 \cdot K}+.33>e^{0.0614 \cdot K}$, which depends on $\mathrm{K}$. When $\mathrm{K}$ is low, the mutual fund dominates. When $\mathrm{K}=5$, for example, the after-tax value of the taxable fund is 1.36 , while the value of the variable annuity is 1.33 . At $K=13$, the advantage switches to the variable annuity. Indeed, if the horizon is 40 years, the value of the taxable equity index fund is 11.66 , while the variable annuity is worth 16.77. It is worth noting, however, that this simple analysis may overstate the advantage of a variable annuity because it ignores the ability to use realized capital losses on taxable mutual funds to offset taxable gains (or up to $\$ 3000$ per year in ordinary income).

The data in Table 1 suggest that the expenses associated with a variable annuity will typically exceed those on the equity mutual fund. Assuming that the expense ratio for the variable annuity exceeds that on the mutual fund by g, one can compute the greatest possible $g$ such that the after-tax terminal wealth from the variable annuity will exceed that from the mutual 
fund. Results of these calculations are shown in table 2. Under pre-2003 tax rates and assuming that the taxable mutual fund has a post-expense rate of return of 8 percent, at a horizon of 20 years, for example, expense differentials of less than 37 basis points will still result in a higher value with the variable annuity. Given an average expense differential between mutual funds and variable annuities of 73 basis points, one would have to hold the investment for 31 years in order for the tax advantage of variable annuities to offset the expense differential. Under the tax law that took effect in mid-2003, the Jobs and Growth Tax Relief Reconciliation Act, the maximum tax rates on both dividends and capital gains are 15 percent. In this case the value of $g$ falls substantially, and indeed becomes negative for holding periods as long as 29 years, meaning that for shorter holding periods a taxable account will yield higher account balances even with an identical cost structure. Even with a horizon of 40 years, under the new tax rates, variable annuities provide a higher net of tax return only if the expense differential is under 25 basis points. This reversal of past patterns is due to the reduction in the tax rate on dividends and capital gains at a time when the tax rate on withdrawals from variable annuities was not reduced.

\subsection{Insurance Features of Variable Annuities}

Variable annuities offer a range of potential insurance features. In particular, if the VA owner dies before converting to a life annuity, the insurance company will typically provide some form of a minimum guaranteed death benefit. Milevsky and Posner (2001) explain that a typical benefit stipulates that at least the original investment will be returned to the estate or the beneficiary of the policy, regardless of the performance of the underlying assets in the account. In other words, when a person buys a variable annuity, they are in part purchasing a put option that has a nominal strike price equal to the nominal amount of their contributions.

This put option is the least valuable option that variable annuities provide. Many providers 
offer a guaranteed death benefit that set benefits at various "high water marks," meaning that they lock-in some portion of past investment returns. For example, a "Maximum Anniversary Value" feature guarantees the maximum value that the investment achieves on a specified date, usually the contract anniversary date. In other words, the insurer guarantees to pay out the higher of the value of i) the purchase price, ii) the highest value on any anniversary date, or iii) the value of the account at the date of death. Alternatively, companies may offer minimum growth guarantees. In this case, the insurer offers a death benefit that is equal to the actual account balance or the value of the premiums compounded at a specified rate of interest. This particular death benefit is often offered as a rider at additional cost to the individual.

Milevsky and Posner (2001) use option pricing techniques to compute the actuarially fair value of the insurance component of these guarantees. They find that "a simple return of premium death benefit is worth between one to ten basis points, depending on purchase age. In contrast to this number, the insurance industry is charging a median Mortality and Expense Risk charge of 115 basis points, although the numbers do vary widely for different companies and policies." In evaluating this claim, however, one should remember that the "one to ten basis point" valuation is only of the simplest death benefit. In recent years, the array of insurance benefits offered through variable annuity products has become more diverse and complex, with features that are often firm or contract specific. During 2001 and 2002, after a sharp decline in equity markets, some of these insurance components proved very expensive for insurance companies. Policy provisions that guaranteed variable annuity buyers the value of their portfolio at past policy anniversaries committed insurance firms to substantial payouts in a declining equity market. For example, Treaster (2003) reports that the Hartford Financial Services Group, which in the year 2000 paid out only \$5.4 million as a result of variable annuity guarantees, faced payouts of \$258 million during 
the bear market of 2002 .

\section{SCF Data and Summary Patterns of Variable Annuity Ownership}

We explore the cross-sectional patterns of variable annuity ownership using the 1998 and 2001 Surveys of Consumer Finances. The 1998 SCF is the first to clearly identify household ownership of variable annuity products. ${ }^{7}$ In particular, the SCF asks "do you (or anyone in your family living here) receive income from or have assets in an annuity?" Respondents are specifically told to exclude employment-related pensions, or any assets that had already been recorded earlier in the survey. They are then asked to distinguish between annuities set up to provide income only versus those that "have an equity interest." We identify variable annuity owners as those who report having an equity interest that is invested in financial assets (stocks, bonds, money market, real estate, diversified, etc.). We exclude those who report that their annuity is invested in life insurance/fixed contracts, tangible assets other than real estate, intangible assets, and other assets, since these are unlikely to be standard variable annuities. We suspect that our definition is conservative and that we have excluded some households who hold variable annuities.

Our analysis of the 1998 SCF suggests that 4.8 million households own variable annuities. The total value of the variable annuities reported in the 1998 survey is $\$ 255$ billion. For the same year, the American Council on Life Insurance (1999) reports that there were 14.6 million variable annuity policies in force, with total asset reserves of $\$ 354$ billion. There is no reason to think that the number of households should match the number of policies, as households may have multiple policies even with the same insurer. However, we would ideally want the value of assets in the SCF to match the asset reserves reported by life insurers. The

\footnotetext{
${ }^{7}$ Earlier waves of the SCF, such as that fielded in 1995, combine annuities in with several other investment products, making it difficult to obtain a precise measure of variable annuity ownership.
} 
SCF measure is roughly three quarters of the ACLI number. We suspect that this is because some variable annuity owners reported the assets in these accounts elsewhere on the survey, perhaps as other financial assets.

Table 3 presents summary information on the characteristics of households that own variable annuities in 1998 and 2001. The first two columns indicate the percentage of households in various sub-categories each year that own variable annuities, while the third and fourth columns show the percentage of all variable annuities that are owned by households in each category. Columns one and two show that just under 4 percent of households reported owning a variable annuity in 1998. By 2001, this figure had increased to 4.65 percent. Not surprisingly, ownership is highly correlated with income and net worth. In the bottom half of the income distribution, for example, just over 2 percent of the population own variable annuities. In the top decile, the ownership rate is over 10 percent in 2001. Ownership is even more highly concentrated by net worth deciles, with 16 percent of the top net worth decile owning variable annuities. From 1998 to 2001, overall growth in ownership rates appears to be largely concentrated at the upper end of the net worth distribution, particularly in the top quintile.

Older households are more likely to own variable annuities. Less than two percent of households under the age of 45 own variable annuities. This rate rises to 5.7 percent in the "preretirement" ages of $45-64$, and nearly nine percent for age $65+$ households. Variable annuity ownership is also steeply rising with education level, with 12.45 percent of households with more than a college education reporting ownership of an annuity, compared with less than three percent of those with a high school education or less.

The last two columns of Table 3 show that variable annuity ownership is highly concentrated among high income and high net worth groups. In 2001, 38 percent of variable 
annuities were held by households in the top decile of the income distribution, and more than half were held by those in the two top deciles. Since many retired households may have current income that does not reflect their lifetime earnings position, ranking by current income may provide an incomplete indicator of the concentration of variable annuity holdings. The statistics on the net worth of variable annuity holders may be more revealing. More than seventy percent of variable annuities are held by households in the top ten percent of the wealth distribution, and only fifteen percent are held by households who are not in the top fifth of the wealth distribution.

Table 3 also stratifies households by their marginal federal income tax rates and then tabulates the probability of owning a variable annuity. The tax rate variable that we use is the marginal income tax rate on ordinary investment income for each household in the 1998 and 2001 SCF. We use an updated version of the algorithm developed by Poterba and Samwick (2003), which estimates a "first dollar" marginal tax rate on investment income. This tax rate is computed in two steps. First, we set interest and dividend income to zero and find the household's federal income tax payment. Then, we assume that the household receives interest income equal to the maximum of $\$ 100$ or five percent of its total financial assets, and we recompute its tax liability. The marginal tax rate on investment income is then defined as the difference in the tax liability divided by the amount of investment income imputed to the household.

Our tax rate algorithm imputes as many items on the 1040 as possible on the basis of data from the SCF. Filing status is determined by the household's marital status, with all married households assumed to file a joint return. Personal exemptions are estimated based on marital status and the number of dependents in the household under age 18. The SCF reports information on many of the components of total income. Wages and salaries, tax-exempt 
interest, alimony received, rents and royalties, business income, and farm income are all defined similarly in the SCF and for tax purposes. Unfortunately, many other income and deduction items, such as IRA distributions and refunds of state and local taxes, are not reported in the SCF.

We make several calculations and imputations to estimate adjustments to total income, which in turn affect tax liability. Self-employment tax applies to all business and farm income. IRA and Keogh contributions can be imputed based on information in the survey, but we set these contributions to zero for the purposes of the marginal tax rates used in this paper. The SCF also includes data on alimony paid, and this is an adjustment to income. There is no data on other adjustments that are allowed on form 1040, such as moving expenses, so we set these items to zero. Subtracting the total adjustments from total income gives the household's AGI. We also estimate whether each household will itemize deductions on Schedule A. The SCF reliably reports information on interest payments and charitable contributions. Deductions for local taxes are based on the reported value of real estate and personal property subject to tax. Itemization is determined by comparing the sum of these deductions to the standard deduction appropriate for the household's age and filing status.

The lack of reported information on other possible deductions, such as medical expenses, state and local income taxes, casualty losses, and job expenses is the biggest handicap in calculating tax rates in the SCF. The household's exemptions and deductions are then subjected to the applicable income-based limits, and they are subtracted from AGI to compute taxable income. Applying the appropriate tax rate schedule to taxable income gives the household's tax liability. Total taxes equal this liability measure, plus self-employment taxes and alternative minimum taxes. We did not compute tax credits, since the SCF does not contain the information needed to evaluate most of them. 
The last four rows of Table 3 present the results with households stratified by marginal tax rates. In both 1998 and 2001, the probability of owning a variable annuity is higher for households with high marginal tax brackets than for those in low tax brackets. In both years the lowest probabilities of ownership are for those with tax rates of less than 21.5 percent. These households do not have ownership rates exceeded 3.5 percent. Most of these households would either be in the 15 percent income tax bracket, or would be in a zero tax bracket group. In 2001, households facing the highest income tax rates, those above 35 percent, have a lower probability of owning variable annuities (8.3 percent) than households with tax rates just below the top range (11 percent). The pattern is different in 1998, when the highest probability of owning a variable annuity is observed among households with the highest marginal tax rates.

The last two columns and last four rows of Table 3 show the fraction of variable annuities held by households in different tax rate categories. The 1998 data show that more than a quarter of all variable annuities are held by households with marginal tax rates of 35 percent or greater. Only ten percent of these assets are held by households who are assigned very low marginal tax rates by our algorithm. The results for 2001 suggest a shift in the concentration of variable annuity ownership toward lower income tax brackets. Only fifteen percent of variable annuities are held by those at marginal tax rates of 35 percent or above, while there is an increase in the share of variable annuities that are reported by households with tax rates between 7.5 and 21.5 percent. The share of variable annuities held by those with very low marginal tax rates was lower in 2001 than in 1998.

While variable annuity ownership is a strongly increasing function of income, net worth, age and education, this is true for most financial instruments. Table 4 presents information on the probabilities of holding variable annuities, taxable bonds, corporate stock, mutual funds, and tax-free assets such as tax-exempt bonds and mutual funds. The sharply rising probability of asset ownership 
by income and net worth categories is evident for taxable bonds and tax-exempt bonds as well as for variable annuities. For example, in 2001, the ratio of the top to the bottom income decile ownership rate was approximately 20 for variable annuities, while it was 26 for bonds, 25 for stocks, 18 for mutual funds and 22 for tax-exempt assets. The wealth-ownership profile is also steeply rising for variable annuities and other asset classes. The age-ownership profile for variable annuities is much steeper than that for stocks or mutual funds. Table 4 shows clearly that the probability of ownership for variable annuities is substantially lower than the analogous probabilities for stocks or mutual funds, but that this probability is comparable to the ownership probability for both taxable and tax-exempt bonds.

Table 5 presents information on the percentage of various asset classes that is held by households at different points in the age, wealth, income, education, and marginal tax rate distribution. The underlying data are drawn from the $2001 \mathrm{SCF}$. The table shows that variable annuity ownership is less concentrated than the ownership of the other asset types. For example, less than 75 percent of variable annuity holdings are in the top decile of the wealth distribution, compared with more than 90 percent for taxable bonds, corporate stock, and tax-exempt bonds. For mutual funds, the most broadlyheld of the financial asset categories, the top tenth of the wealth distribution holds 79 percent of the total. One striking feature of Table 5 is the evidence that older households hold a higher fraction of variable annuities than of other financial assets. Households headed by someone over the age of 65 hold nearly half of all variable annuities, compared with roughly one third of all of the other financial asset categories we consider. The concentration of stock, bond, and tax-exempt bond ownership among the highest marginal income tax rate households is also greater than the analogous concentration for variable annuities.

Tables 4 and 5 present information on the ownership of variable annuities and other assets, but they do not explore the inter-relationships between the holdings of these assets. Tables 6 and 7 address this issue. We explore the cross-ownership patterns between variable annuities, other tax 
deferred savings vehicles, stocks, mutual funds, and tax-free assets. If variable annuities are viewed primarily as vehicles for tax-favored asset accumulation, but with higher expense ratios than the investment vehicles that can be held in IRAs, Keogh plans, and other tax-deferred accounts, then we would expect to see a high fraction of variable annuity owners also holding these accounts.

The results in Table 6, which reports the probability that investors who hold one asset also hold another, offer only limited support for this prediction. Nearly two thirds (63 percent) of households with variable annuities also hold IRAs or Keoghs. While this is consistent with substantial use of tax-deferred saving vehicles by variable annuity investors, the share of variable annuity holders with IRAs or Keoghs is no higher than the share of mutual fund or corporate stock investors. Moreover, only 42 percent of variable annuity investors hold corporate stock, and 22 percent hold tax-free bonds, even though these are the other tax-favored asset classes that one would expect to find in the portfolio of an investor who was trying to maximize tax-free asset accumulation.

Table 7 presents information similar to that in Table 6 , but instead of reporting the probability that investors in a given asset class hold another asset, it reports the fraction of assets in a given asset class that are held by investors who also hold another asset. Thus, in the first row, 73 percent of all variable annuities are held by investors who also hold assets in an IRA or a Keogh. Fifty-seven percent of variable annuity assets are held by households that also hold corporate stock. The results are broadly similar to those in Table 6 , in that they do not suggest large differences in the share of variable annuity investors and investors in other asset categories who hold assets in tax-deferred accounts.

The critical question that is not resolved by Tables 6 or 7 is whether households turn to 
variable annuities after they have exhausted other opportunities for tax-deferred saving. The SCF does not provide data on contributions to tax-deferred saving accounts, so we cannot identify households who are constrained by the contribution limits for these accounts. These constraints are clearly relevant for households with employment income. For retired households, the decision to invest in a variable annuity should hinge on the expected investment horizon and the costs and expenses associated with the variable annuity product. Without more detailed information on the other options available to each household, it is difficult to test for a hierarchy of investment choices.

\section{Analyzing the Demand for Variable Annuities}

We now consider multivariate evidence on the factors that are associated with ownership of variable annuities. We focus on tax considerations and insurance demand. With respect to taxation, we study the relationship between marginal tax rates and ownership, conditioning on other household financial and demographic characteristics. Deferring taxes on interest and dividends is worth more to investors in high marginal tax brackets than to those in low brackets, so it is natural to explore the patterns of variable annuity ownership as they relate to marginal tax rates. We do this by including a set of indicator variables for household marginal tax rates in our probit models. Rather than simply adding the household's marginal tax rate as an explanatory variable, we construct four indicator variables to capture four distinct ranges of household marginal tax rates. This lets us test for differences in variable annuity demand, conditional on other covariates, between households in the 39.6 percent marginal tax bracket, the 33 percent marginal bracket, and lower marginal rates. One of the key difficulties with such research is disentangling the impact of marginal tax rates from the effect of variation in household income. We try to address this issue by including nonlinear functions of income in our empirical model. 
We also consider the role of insurance demand in explaining purchases of variable annuities. To the extent that the insurance component of variable annuity products has substantial value above and beyond the actuarially fair price, we might expect that more risk averse consumers would be more likely to purchase them. To test for this, we focus on responses to the following question in the SCF:

"Which of the following statements on this page comes closes to the amount of financial risk that you and your (spouse/partner) are willing to take when you save or make investments?

1. Take substantial financial risks expecting to earn substantial returns

2. Take above average financial risks expecting to earn above average returns

3. Take average financial risks expecting to earn average returns

4. Not willing to take any financial risk.

These measures have been used in Weisbenner's (2002) study of stock ownership. We define four indicator variables for positive responses to each of these four questions.

We estimate probit models to explain the household's discrete choice of whether or not to own a variable annuity. The basic specification for the model that we estimate on the 1998 and 2001 SCF is:

$\operatorname{Pr}($ OwnVA $=1)=F\left(\begin{array}{l}\beta_{0}+\beta_{1} \cdot \text { MTR }+\beta_{2} \cdot \text { RiskAversion }+\beta_{3} \cdot \text { Income }+\beta_{4} \cdot \text { Networth }+\beta_{5} \cdot \text { Age } \\ +\beta_{5} \cdot \text { Education }+\beta_{6} \cdot \text { HavePension }+\beta_{7} \cdot \text { HaveIRA }+\beta_{8} \cdot \text { Other }\end{array}\right)$

Our marginal tax rate variables (MTR) and risk aversion variables are as defined above. Due to the strongly non-linear relationship between variable annuity ownership, income, and net worth, we include these variables non-linearly. In particular, we include dummy variables for quintiles of income and net worth, and category dummy variables for age and education. "Other" includes indicator variables for being married, widowed, and whether the household has children. We assume that $\mathrm{F}($.$) is the cumulative distribution function associated with the normal distribution,$ 
and therefore estimate probit models. All coefficient estimates reported in Table 8 are marginal effects, $\operatorname{dPr}(\mathrm{OwnVA}=1) / \mathrm{dX}$. These probability derivatives are reported instead of probit model coefficients to facilitate interpretation.

Table 8 reports both weighted and unweighted results, with the weights equal to the population sampling weights for each observation. By comparing weighted and unweighted coefficient estimates we can obtain some evidence on the robustness of our findings. We present results for 1998 as well as 2001 . We focus first on the hypothesis that tax factors contribute to variable annuity demand. In 1998, even after conditioning on a full set of covariates, notably including five income categories, the indicator variables for high marginal tax rates have a positive effect on variable annuity demand, and we can reject the null hypothesis of a zero coefficient at the 95 percent level. The interpretation of these coefficients is that a move from having a zero marginal tax bracket to the 15 percent tax bracket, conditional on income, net worth and other covariates raises the probability of owning a variable annuity by 1.37 percent. The coefficients on the higher brackets are even larger. For example, the largest effect comes in at the 31.9 percent marginal rate, where we observe a 3.7 percent jump in the likelihood of owning a variable annuity contract relative to the zero marginal tax bracket. The baseline level of variable annuity ownership is only four percent, so this effect looms large relative to this standard. The weighted and unweighted results for the marginal tax rate variables in 1998 are broadly similar.

The 2001 cross-sectional results, however, are quite different from those for 1998. The coefficients on the marginal tax rate variables and the income variables trade signs in the two key specifications. In 1998, the probit coefficients on the indicators for high marginal tax rates are substantial and positive. There are negative coefficients on some of the income variables. In 
2001, all of the tax variables have negative coefficients that are statistically indistinguishable from zero, while all of the income variables have positive coefficients that are also not significantly different from zero at conventional confidence levels.

The instability in the marginal tax rate and income decile coefficients is disturbing, but it should not be surprising. Table 3 showed some differences between 1998 and 2001 in the ownership probabilities for variable annuities across different marginal tax rate categories. Whether this disparity is due to real changes in household behavior, or to small sample sizes for the variable annuity population, is not clear. Moreover, since marginal income tax rates and household income are highly correlated, it is very difficult for the probit models to separately identify their effects. This may contribute to the instability across sample years. This is not an insurmountable problem, however, since other studies of tax rates and portfolio holdings, such as Poterba and Samwick (2003), have identified reasonably stable behavioral relationships between tax rates and portfolio outcomes, and done so with controls for income and net worth.

We explored potential sources of the difference between the 1998 and 2001 results. There is some change in the structure of marginal tax rates in 2001 as a result of the Economic Growth and Taxpayer Relief Reconciliation Act, and households may have made choices based on their previous tax rates rather than the rates that they faced in 2001 . We therefore tried replacing the marginal tax rates that we estimated using 2001 tax law with marginal tax rates estimated using 1998 tax law. In this case, however, the coefficients on the tax variables were not substantially different from those in Table 8 . Had we analyzed only the 1998 SCF we would have concluded that taxes had an important effect on the demand for variable annuities. However, the 1998 and 2001 data sets together do not yield a clear conclusion. We are currently trying to understand the source of the differences between the 1998 and 2001 results. 
With regard to risk aversion, we find a negative relationship between increasing levels of risk aversion and variable annuity ownership. This pattern emerges in 1998; in 2001, the coefficients on the risk aversion indicator variables are statistically indistinguishable from zero. When there is an effect, it seems that more risk averse individuals are less likely to purchase variable annuities. This is sharply at odds with the idea that individuals are purchasing variable annuities primarily because of their insurance benefits. There are several potential reasons for this finding. One is that risk averse consumers would prefer to hold more traditional forms of insurance, such as standard term life insurance contracts, as a way of providing financial protection to beneficiaries. However, it may also be a data limitation, in that the risk aversion questions in the SCF are general and do not relate to the types of risks that variable annuities offer protection against, such as the risk of a decline in asset values that might make it difficult to finance retirement.

It is also possible that the risk aversion questions are capturing household attributes that affect both wealth generation and wealth allocation. If households that are more risk-tolerant are likely to accumulate more assets over the course of their lifetimes, then they are more likely to have the financial resources needed to purchase variable annuities. Our wealth indicators may not completely capture the differences in financial resources, and this may be reflected in the coefficients on the risk aversion variables.

While neither the tax nor the risk aversion variables consistently point in the directions that we expected, there are several other interesting coefficient patterns in Table 8. For example, once we have controlled for net worth, education, age, and marginal tax rates, the partial effect of income on holdings of variable annuities is small, and indeed negative and significant for the second and third quintile relative to the omitted first quintile. The interpretation of the income 
coefficients is complicated, however, by the strong correlation between the various independent variables. We do observe an economically and statistically significant effect of net worth in both sample years. Being in the upper the upper two quintiles of the net worth distribution raises the probability of ownership by between three and six percentage points. Education also has a strong positive effect on variable annuity ownership in 1998, but like the tax variables, the coefficient changes sign in the 2001 sample.

We are currently working to understand the contrast between the coefficient patterns in the 1998 SCF and the 2001 surveys. Holdings of variable annuities increased between the two surveys, with roughly seven tenths of a percentage point of the population more holding variable annuities in 2001 than in 1998. Yet the cross-sectional partial effects of income, net worth, our measured tax rates, and other household characteristics appear to differ in the two years. It is possible that this is an artifact of the small sample sizes of the variable annuity holding

population. With only about 150 households in our estimation sample owning variable annuities, it is possible that our results could be affected by outliers or other small sample considerations.

\section{Conclusions and Future Directions}

In this paper, we document the rapid growth during the 1990s of the market for variable annuities. Annuity sales grew more rapidly than net flows into this market, as many variable annuity contracts were terminated and the assets were transferred to new annuities. We identify two factors, the opportunity for tax deferral and the insurance features of these products, which might contribute to the growth of variable annuities. We then provide the first evidence, from the 1998 and 2001 waves of the Survey of Consumer Finances, of variable annuity ownership patterns in the U.S. 
In a univariate framework, we find that ownership is strongly increasing with income, wealth, age, and education. Importantly, however, we find that ownership of variable annuities across the education, income and net worth distribution is less concentrated than ownership of most other financial assets. Compared to other financial assets, variable annuities are more heavily concentrated at extended ages.

The SCF and other household surveys currently lack sufficient detail on payout behavior to facilitate such a detailed analysis of how households decide whether to take a lump sum payout or a stream of annuitized payouts. We hope that this data deficiency will be addressed in future surveys, and that we can then determine how many households are choosing lump-sum payouts rather than various annuity options.

Our probit models findings for the $1998 \mathrm{SCF}$ a strong effect of higher marginal tax rates on variable annuity demand, with a move from a zero percent marginal tax rate to a 32 percent rate resulting in a 3.7 percentage point increase in the probability of owning variable annuities. However, such a tax effect is not evident in the 2001 data, and there is similar instability across waves of the SCF in the coefficients on other factors. We are reluctant to draw any firm conclusions about the link between tax incentives and annuity purchases because of the lack of robustness of these results across samples. It is worth noting that other studies of insurance demand for results that are difficult to explain. For example, a long line of studies in the area of life insurance, such as Bernheim, et al. (2003), find a weak relationship between financial vulnerabilities and insurance purchases. While that evidence is based on life insurance rather than investment products, it confirms the old adage that "insurance is sold, not bought."

Our analysis offers a useful starting point for the analysis of variable annuity demand, but due to data issues, it leaves many issues unresolved. Going forward, our hope is that household 
surveys will continue to improve the data collection on variable annuity products so that we can learn more about how demand is affected by tax and other considerations. For example, the most recent tax reform has substantially altered the incentives for investing in variable annuities relative to alternative investment products. A careful examination of how this tax change affects incentives and behavior may shed additional light on this issue.

Another issue that requires future analysis is the computation of effective load factors on variable annuities, and the comparison between these loads and those on other insurance products. For example, Mitchell, et al (1999) find loads on fixed life annuity products of around 15 percent, and Brown and Finkelstein (2003) find loads on long-term care insurance as high as 50 percent for men. Computing the loads on variable annuities is more difficult than computing the loads on some other insurance products, because the return to a variable annuity investor depends critically on the investor's behavior. If the variable annuity is held for many years, and if the payouts are withdrawn as annuity payments, the net after-tax and after-expense return may be substantially greater than if the variable annuity is transferred to another insurance carrier after just a few years. 


\section{References}

Bernheim, B. Douglas, Katherine Carman, Jagadeesh Gokhale, and Laurence Kotlikoff. 2003. “Are Life Insurance Holdings Related to Financial Vulnerabilities?" Economic Inquiry 41, p. 531-554.

Bodie, Zvi and James Pesando. 1983. "Retirement Annuity Design in an Inflationary Climate." In Zvi Bodie and John Shoven, eds. Financial Aspects of the U.S. Pension System (Chicago: University of Chicago Press.)

Brown, Jeffrey R. and Amy Finkelstein. 2003. "High Prices, Limited Benefits: New Evidence on the Long-Term Care Insurance Market." Working paper.

Brown, Jeffrey R., Olivia S. Mitchell and James M. Poterba. 2001a. "The Role of Real Annuities and Indexed Bonds in an Individual Accounts Retirement Program." In John Y. Campbell and Martin Feldstein, eds., Risk Aspects of Investment-Based Social Security Reform. (Chicago: The University of Chicago Press.) $321-360$.

Brown, Jeffrey R., Olivia S. Mitchell, James M. Poterba and Mark J. Warshawsky. 2001b. The Role of Annuities in Financing Retirement. (Cambridge: The MIT Press.)

Brown, Jeffrey R. and Mark J. Warshawsky. 2001. "Longevity Insured Retirement Distributions from Pension Plans: Market and Regulatory Issues." NBER Working Paper 8064.

Cerulli Associates, Inc. 2001. "The State of the Annuity Industry." The Cerulli Report.

Gentry, William M. and Joseph Milano. 1998. "Taxes and the Increased Investment in Annuities," NBER Working Paper 6525.

Milevsky, Moshe A. and Steven E. Posner. 2001. "The Titanic Option: Valuation of the Guaranteed Minimum Death Benefit in Variable Annuities and Mutual Funds," The Journal of Risk and Insurance, Vol. 68, No. 1, 93-128.

Mitchell, Olivia S., James M. Poterba, Mark Warshawsky, and Jeffrey R. Brown. 1999. "New Evidence on the Money's Worth of Individual Annuities." The American Economic Review. Vol. 89 (December), 1299-1318.

Poterba, James M. and Andrew A. Samwick. 2003. "Taxation and Household Portfolio Composition: U.S. Evidence from the 1980s and 1990s." Journal of Public Economics 87, 5-39.

Treaster, Joseph B. April 6, 2003. "Mutual Fund Reports: Annuity Death Benefit Starts Paying Its Way." New York Times, Section 3, page 16, column 1.

Weisbenner, Scott. 2002. "Do Pension Plans with Participant Investment Choice Teach Households to Hold More Equity?" The Journal of Pension Economics and Finance, Vol. 1, No. 3, 223-248.

Weiss Ratings. 2002. "Consumer Guide to Variable Annuities." 


\section{Figure 1}

Variable Annuity Considerations (\$ Billions)

Source: ACLI Life Insurers Fact Book 2002

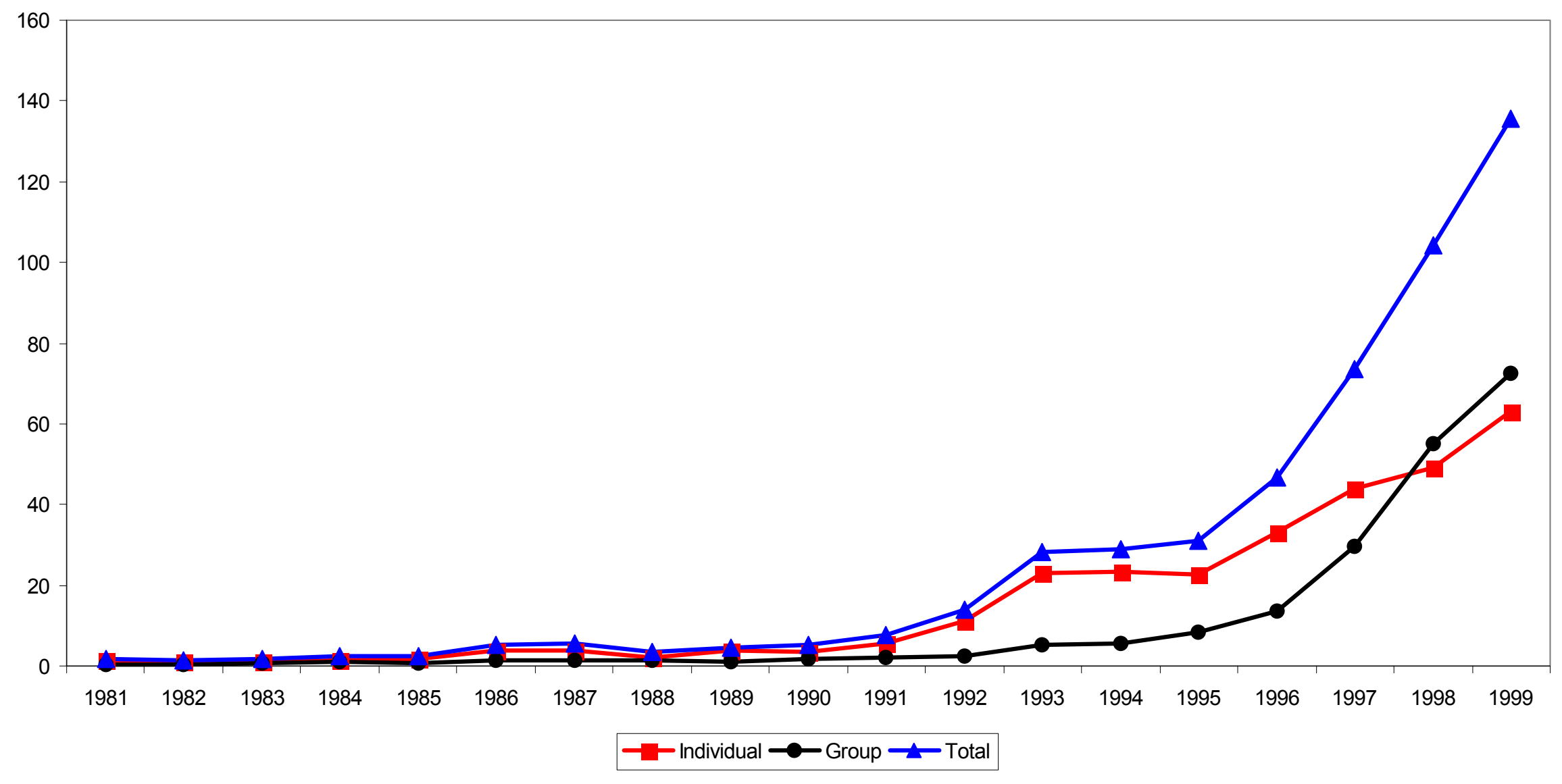


Figure 2:

Variable Annuity Net Flows vs. Total Sales

1995-2001 (\$ billions)

Source: Cerulli Associates, Inc. (used with permission)

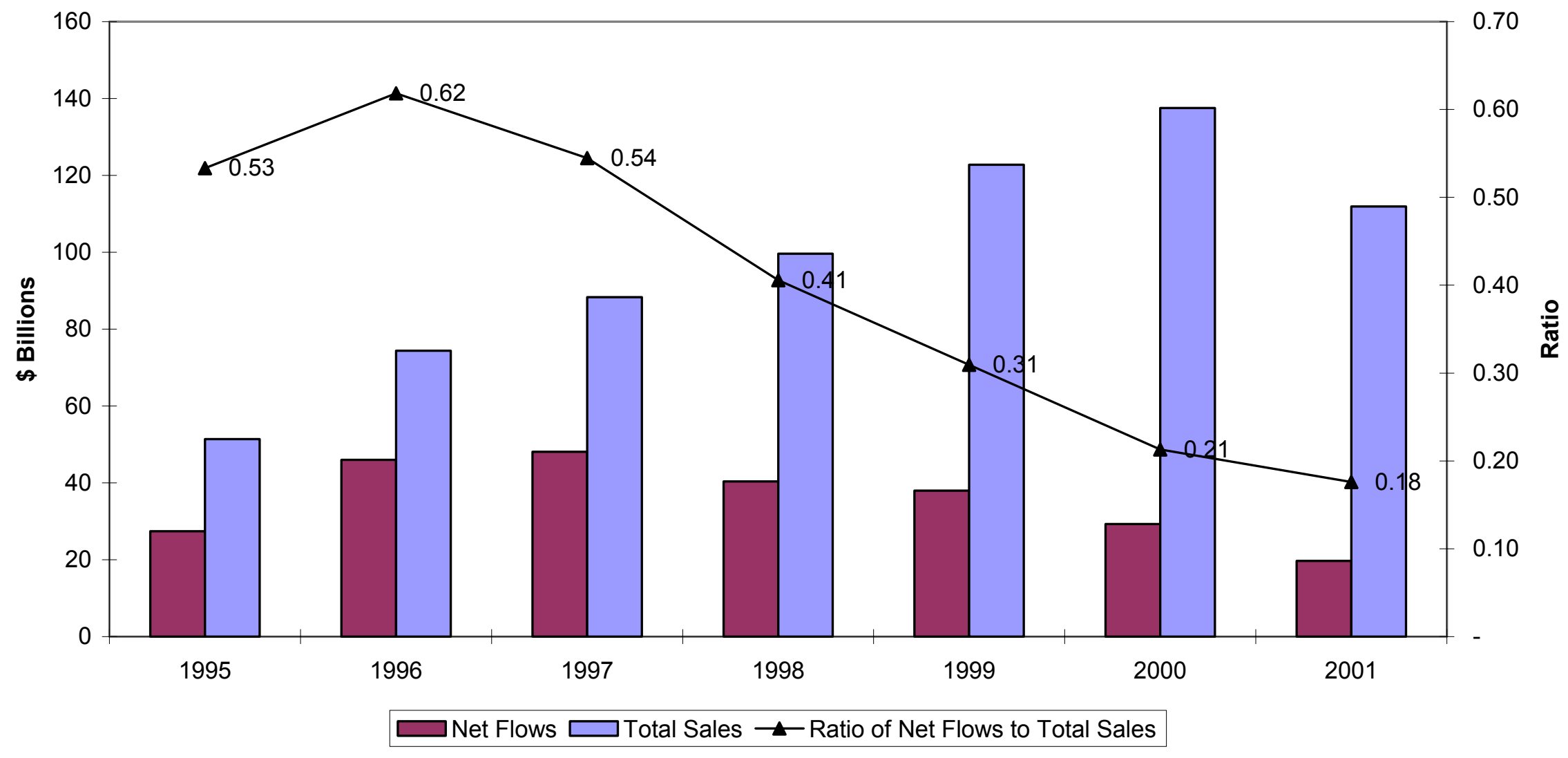


Table 1: Expenses and Insurance Costs, Variable Annuities and Mutual Funds, Weighted by Assets Under Management, 2002

\begin{tabular}{|l|c|c|c|c|}
\hline \multirow{2}{*}{\begin{tabular}{l} 
Objestment \\
\cline { 2 - 4 }
\end{tabular}} & $\begin{array}{c}\text { Management } \\
\text { Expense }\end{array}$ & Insurance Charge & Total Expenses & \\
\hline All & 0.57 & 1.09 & 1.65 & 0.92 \\
\hline Balanced & 0.61 & 1.20 & 1.80 & 0.79 \\
\hline Corporate Bond & 0.55 & 1.13 & 1.68 & 0.72 \\
\hline $\begin{array}{l}\text { Government } \\
\text { Bond }\end{array}$ & 0.61 & 1.30 & 1.91 & 0.90 \\
\hline Growth & 0.70 & 1.23 & 1.93 & 1.04 \\
\hline $\begin{array}{l}\text { Growth \& } \\
\text { Income }\end{array}$ & 0.34 & 0.81 & 1.15 & 0.66 \\
\hline High Yield Bond & 0.70 & 1.29 & 1.99 & 1.09 \\
\hline $\begin{array}{l}\text { International } \\
\text { Bond }\end{array}$ & 1.01 & 1.33 & 2.34 & 1.05 \\
\hline $\begin{array}{l}\text { International } \\
\text { Stock }\end{array}$ & 0.84 & 1.17 & 2.01 & 1.11 \\
\hline
\end{tabular}

Source: Authors' tabulations from 2002 Morningstar Variable Annuities and Mutual Funds databases. Costs and expenses are measured in hundreds of basis points per year.

Table 2: Expense Differential (Variable Annuity Expenses - Mutual Fund Expenses) such that Investor would Accumulate Equal Wealth, by Holding Period (in basis points per year, assuming 8 percent rate of return)

\begin{tabular}{|c|c|c|}
\hline Holding Period (years) & Pre-2003 Tax Rates & Post-2003 Tax Rates \\
\hline 5 & -59 & -145 \\
\hline 10 & -18 & -98 \\
\hline 15 & 13 & -63 \\
\hline 20 & 37 & -36 \\
\hline 25 & 55 & -15 \\
\hline 30 & 70 & 1 \\
\hline 35 & 83 & 14 \\
\hline 40 & 93 & 25 \\
\hline
\end{tabular}

Source: Authors' calculations assuming 8 percent return (2 percent from dividends, 6 percent from capital gains). Assumed tax rates for pre-2003 period are 20\% for capital gains, 33\% for dividends and ordinary income. For post-2003, rates are 15\% for capital gain and dividends, and $33 \%$ for ordinary income. 
Table 3: Summary Statistics on Variable Annuity Ownership, 1998 and 2001

\begin{tabular}{|c|c|c|c|c|}
\hline & \multicolumn{2}{|c|}{$\begin{array}{l}\text { Percentage of Households Owning } \\
\text { Variable Annuities }\end{array}$} & \multicolumn{2}{|c|}{$\begin{array}{l}\text { Percentage of Variable Annuities Held } \\
\text { by Households in Each Category }\end{array}$} \\
\hline & 1998 & 2001 & 1998 & 2001 \\
\hline All Households & $3.98 \%$ & $4.65 \%$ & $100.0 \%$ & $100.0 \%$ \\
\hline \multicolumn{5}{|c|}{ Households Grouped by Age } \\
\hline$<35$ & 1.02 & 1.74 & 3.5 & 4.5 \\
\hline $35-44$ & 2.38 & 2.06 & 15.2 & 6.5 \\
\hline $45-64$ & 4.50 & 5.68 & 51.5 & 39.3 \\
\hline $65+$ & 8.13 & 8.88 & 29.9 & 49.7 \\
\hline \multicolumn{5}{|c|}{ Households Grouped by Education } \\
\hline$<$ High School & 1.16 & 3.41 & 3.9 & 3.5 \\
\hline High School & 3.07 & 2.13 & 9.8 & 14.9 \\
\hline Some College & 3.22 & 4.11 & 17.2 & 22.9 \\
\hline College & 3.96 & 5.48 & 21.8 & 27.8 \\
\hline$>$ College & 12.28 & 12.45 & 47.4 & 30.9 \\
\hline \multicolumn{5}{|c|}{ Households Grouped by Income Decile } \\
\hline Lowest Decile & 1.76 & 0.53 & 1.3 & 1.5 \\
\hline Decile 2 & 1.86 & 2.22 & 2.2 & 3.5 \\
\hline Decile 3 & 0.97 & 1.06 & 1.7 & 2.5 \\
\hline Decile 4 & 3.48 & 3.67 & 5.8 & 1.6 \\
\hline Decile 5 & 3.45 & 3.28 & 5.8 & 3.7 \\
\hline Decile 6 & 2.82 & 6.01 & 4.7 & 14.4 \\
\hline Decile 7 & 3.43 & 5.77 & 3.7 & 12.7 \\
\hline Decile 8 & 7.03 & 6.71 & 18.0 & 8.4 \\
\hline Decile 9 & 5.61 & 7.52 & 8.1 & 14.9 \\
\hline Highest Decile & 9.50 & 10.43 & 48.7 & 38.1 \\
\hline \multicolumn{5}{|c|}{ Households Grouped by Wealth Decile } \\
\hline Lowest Decile & 0.45 & 0.00 & 0.0 & 0 \\
\hline Decile 2 & 0.00 & 0.00 & 0.0 & 0 \\
\hline Decile 3 & 0.43 & 0.36 & 0.0 & 0 \\
\hline Decile 4 & 0.00 & 1.06 & 0.0 & 0 \\
\hline Decile 5 & 2.23 & 1.75 & 0.5 & 0.2 \\
\hline Decile 6 & 2.18 & 3.11 & 0.9 & 1.3 \\
\hline Decile 7 & 5.92 & 3.14 & 4.9 & 0.7 \\
\hline Decile 8 & 6.91 & 9.01 & 9.6 & 9.0 \\
\hline Decile 9 & 7.61 & 12.23 & 12.9 & 16.1 \\
\hline Decile 10 & 13.81 & 15.93 & 71.1 & 72.7 \\
\hline \multicolumn{5}{|c|}{ Households Grouped by Marginal Federal Income Tax Rate (MTR) } \\
\hline MTR $<.075$ & 2.82 & 2.50 & 10.5 & 6.3 \\
\hline $.075<\mathrm{MTR}<.215$ & 2.05 & 3.50 & 8.9 & 23.7 \\
\hline $.215<\mathrm{MTR}<.299$ & 6.43 & 6.24 & 37.9 & 42.2 \\
\hline $.299<\mathrm{MTR}<.350$ & 9.33 & 11.00 & 14.3 & 12.7 \\
\hline $.350<$ MTR & 9.71 & 8.27 & 28.4 & 15.1 \\
\hline
\end{tabular}

Source: Authors' tabulations using 2001 Survey of Consumer Finances. 
Table 4: Probability of Owning Variable Annuities and Other Assets, 2001 SCF

\begin{tabular}{|c|c|c|c|c|c|}
\hline Total & $\begin{array}{c}\text { Variable } \\
\text { Annuities } \\
4.65 \%\end{array}$ & $\begin{array}{c}\text { Taxable } \\
\text { Bonds } \\
3.00 \%\end{array}$ & $\begin{array}{c}\text { Corporate } \\
\text { Stock } \\
21.75 \%\end{array}$ & $\begin{array}{c}\text { Mutual } \\
\text { Funds } \\
17.90 \%\end{array}$ & $\begin{array}{c}\text { Tax- } \\
\text { Exempt } \\
\text { Bonds } \\
6.75 \%\end{array}$ \\
\hline \multicolumn{6}{|c|}{ Households Grouped by Age } \\
\hline$<35$ & 1.74 & 0.40 & 17.57 & 11.50 & 2.66 \\
\hline $35-44$ & 2.06 & 2.04 & 21.76 & 17.64 & 5.17 \\
\hline $45-64$ & 5.68 & 4.12 & 24.50 & 20.90 & 8.96 \\
\hline $65+$ & 8.88 & 5.00 & 21.84 & 20.26 & 9.30 \\
\hline \multicolumn{6}{|c|}{ Households Grouped by Education } \\
\hline$<$ High School & 3.41 & 0.28 & 6.37 & 3.41 & 1.40 \\
\hline High School & 2.13 & 0.89 & 13.15 & 12.44 & 3.72 \\
\hline Some College & 4.11 & 3.06 & 21.28 & 14.97 & 6.34 \\
\hline College & 5.48 & 5.45 & 38.54 & 29.43 & 10.31 \\
\hline$>$ College & 12.45 & 8.44 & 41.84 & 41.31 & 17.61 \\
\hline \multicolumn{6}{|c|}{ Households Grouped by Income Deciles } \\
\hline 1 & 0.53 & 0.49 & 2.50 & 2.78 & 1.08 \\
\hline 2 & 2.22 & 0.22 & 6.01 & 4.90 & 2.28 \\
\hline 3 & 1.06 & 1.44 & 9.20 & 6.87 & 2.50 \\
\hline 4 & 3.67 & 1.45 & 16.20 & 13.81 & 5.40 \\
\hline 5 & 3.28 & 1.35 & 14.76 & 12.92 & 4.28 \\
\hline 6 & 6.01 & 0.81 & 18.28 & 17.98 & 3.98 \\
\hline 7 & 5.77 & 2.86 & 23.01 & 17.44 & 4.63 \\
\hline 8 & 6.71 & 5.73 & 30.32 & 25.10 & 10.11 \\
\hline 9 & 7.52 & 3.27 & 38.65 & 28.88 & 10.59 \\
\hline 10 & 10.43 & 12.62 & 61.26 & 50.25 & 23.61 \\
\hline \multicolumn{6}{|c|}{ Households Grouped by Wealth Deciles } \\
\hline 1 & 0.0 & 0.0 & 6.88 & 2.08 & 1.74 \\
\hline 2 & 0.0 & 0.0 & 0.48 & 0.0 & 0.0 \\
\hline 3 & 0.36 & 0.0 & 4.00 & 0.34 & 0.20 \\
\hline 4 & 1.06 & 0.24 & 4.86 & 4.48 & 2.48 \\
\hline 5 & 1.75 & 0.76 & 11.86 & 11.42 & 2.23 \\
\hline 6 & 3.11 & 0.74 & 21.89 & 12.91 & 3.71 \\
\hline 7 & 3.14 & 1.54 & 21.68 & 17.73 & 5.81 \\
\hline 8 & 9.01 & 2.22 & 31.47 & 28.74 & 6.11 \\
\hline 9 & 12.23 & 5.83 & 47.87 & 44.24 & 15.82 \\
\hline 10 & 15.93 & 18.72 & 66.79 & 57.27 & 29.53 \\
\hline \multicolumn{6}{|c|}{ Households Grouped by Federal Marginal Income Tax Rate } \\
\hline MTR $<.075$ & 2.50 & 1.38 & 7.20 & 6.44 & 2.61 \\
\hline $.075<\mathrm{MTR}<.215$ & 3.50 & 1.82 & 15.20 & 12.83 & 4.36 \\
\hline $.215<\mathrm{MTR}<.299$ & 6.24 & 3.60 & 31.51 & 24.41 & 9.26 \\
\hline $.299<\mathrm{MTR}<.350$ & 11.00 & 6.76 & 46.73 & 47.24 & 14.38 \\
\hline $.350<$ MTR & 8.27 & 13.14 & 60.59 & 45.14 & 23.48 \\
\hline
\end{tabular}

Source: Authors' tabulations using 2001 Survey of Consumer Finances. 
Table 5: Share of Various Assets Held by Different Population Sub-Groups, 2001 SCF

\begin{tabular}{|c|c|c|c|c|c|}
\hline & $\begin{array}{l}\text { Variable } \\
\text { Annuities }\end{array}$ & $\begin{array}{l}\text { Taxable } \\
\text { Bonds }\end{array}$ & $\begin{array}{c}\text { Corporate } \\
\text { Stock }\end{array}$ & $\begin{array}{l}\text { Mutual } \\
\text { Funds }\end{array}$ & $\begin{array}{c}\text { Tax- } \\
\text { Exempt } \\
\text { Bonds }\end{array}$ \\
\hline \multicolumn{6}{|c|}{ Households Grouped by Age } \\
\hline$<35$ & $4.5 \%$ & $3.6 \%$ & $6.3 \%$ & $3.6 \%$ & $4.3 \%$ \\
\hline $35-44$ & 6.5 & 4.8 & 9.3 & 13.0 & 5.7 \\
\hline $45-64$ & 39.3 & 55.5 & 47.7 & 49.8 & 55.1 \\
\hline $65+$ & 49.7 & 36.2 & 36.7 & 33.6 & 34.9 \\
\hline \multicolumn{6}{|c|}{ Households Grouped by Education } \\
\hline$<$ High School & 3.5 & 0.2 & 1.2 & 1.3 & 1.8 \\
\hline High School & 14.9 & 3.2 & 5.4 & 12.9 & 6.7 \\
\hline Some College & 22.9 & 10.9 & 13.4 & 12.3 & 11.7 \\
\hline College & 27.8 & 35.6 & 37.7 & 34.2 & 32.5 \\
\hline$>$ College & 30.9 & 50.1 & 42.3 & 39.3 & 47.4 \\
\hline \multicolumn{6}{|c|}{ Households Grouped by Income Deciles } \\
\hline 1 & 0.1 & 0 & 1.3 & 0.2 & 0.4 \\
\hline 2 & 3.5 & 0.3 & 0.1 & 1.2 & 0.3 \\
\hline 3 & 2.5 & 0.7 & 1.1 & 1.4 & 0.3 \\
\hline 4 & 1.6 & 0.3 & 1.7 & 2.8 & 1.4 \\
\hline 5 & 3.7 & 0.2 & 1.4 & 3.0 & 2.6 \\
\hline 6 & 14.4 & 2.0 & 3.2 & 6.1 & 1.6 \\
\hline 7 & 12.7 & 3.1 & 5.4 & 5.0 & 4.8 \\
\hline 8 & 8.4 & 5.4 & 5.1 & 7.7 & 6.1 \\
\hline 9 & 14.9 & 3.6 & 8.4 & 12.5 & 6.3 \\
\hline 10 & 38.1 & 84.4 & 73.5 & 58.9 & 76.2 \\
\hline \multicolumn{6}{|c|}{ Households Grouped by Wealth Deciles } \\
\hline 1 & 0 & 0 & 0 & 0 & 0 \\
\hline 2 & 0 & 0 & 0 & 0 & 0 \\
\hline 3 & 0 & 0 & 0 & 0 & 0 \\
\hline 4 & 0 & 0 & 0 & 0 & 0.1 \\
\hline 5 & 0.2 & 0.1 & 0.1 & 0.3 & 0.1 \\
\hline 6 & 1.3 & 0.1 & 0.4 & 0.5 & 0.3 \\
\hline 7 & 0.7 & 0.3 & 0.7 & 2.0 & 1.3 \\
\hline 8 & 9.0 & 0.6 & 2.1 & 4.1 & 1.4 \\
\hline 9 & 16.1 & 2.2 & 6.4 & 13.7 & 6.9 \\
\hline 10 & 72.7 & 96.7 & 90.2 & 79.4 & 90.0 \\
\hline \multicolumn{6}{|c|}{ Households Grouped by Federal Marginal Income Tax Rates (MTR) } \\
\hline MTR $<.075$ & 6.3 & 1.0 & 1.6 & 4.9 & 2.3 \\
\hline $.075<\mathrm{MTR}<.215$ & 23.7 & 12.4 & 11.2 & 16.7 & 17.2 \\
\hline $.215<\mathrm{MTR}<.299$ & 42.2 & 16.4 & 23.8 & 29.7 & 18.8 \\
\hline $.299<$ MTR $<.350$ & 12.7 & 15.0 & 16.2 & 16.6 & 13.5 \\
\hline $.350<\mathrm{MTR}$ & 15.1 & 55.3 & 47.3 & 32.0 & 48.1 \\
\hline
\end{tabular}

Source: Authors' tabulations using the 2001 Survey of Consumer Finances. 
Table 6: Cross-Asset Ownership Patterns, 2001

\begin{tabular}{|l|c|c|c|c|c|}
\hline & $\begin{array}{l}\text { Variable } \\
\text { Annuity }\end{array}$ & $\begin{array}{l}\text { IRA / } \\
\text { Keogh }\end{array}$ & $\begin{array}{l}\text { Corporate } \\
\text { Stock }\end{array}$ & $\begin{array}{l}\text { Mutual } \\
\text { Fund }\end{array}$ & $\begin{array}{l}\text { Tax Free } \\
\text { Assets }\end{array}$ \\
\hline Population & 0.05 & 0.32 & 0.22 & 0.18 & 0.07 \\
\hline $\begin{array}{l}\text { Variable } \\
\text { Annuity }\end{array}$ & 1.0 & 0.63 & 0.42 & 0.50 & 0.22 \\
\hline $\begin{array}{l}\text { IRA / } \\
\text { Keogh }\end{array}$ & 0.09 & 1.0 & 0.42 & 0.37 & 0.13 \\
\hline $\begin{array}{l}\text { Corporate } \\
\text { Stock }\end{array}$ & 0.09 & 0.62 & 1.0 & 0.40 & 0.18 \\
\hline $\begin{array}{l}\text { Mutual } \\
\text { Fund }\end{array}$ & 0.13 & 0.65 & 0.48 & 1.0 & 0.25 \\
\hline $\begin{array}{l}\text { Tax Free } \\
\text { Assets }\end{array}$ & 0.15 & 0.63 & 0.57 & 0.66 & 1.0 \\
\hline
\end{tabular}

Notes: Tax Free Assets include tax-exempt bond and money market funds as well as municipal bond funds. All entries are based on population-weighted tabulations from the 2001 Survey of Consumer Finances.

Table 7: Asset-Weighted Cross-Asset Ownership Patterns, 2001

\begin{tabular}{|l|c|c|c|c|c|}
\hline & $\begin{array}{l}\text { Variable } \\
\text { Annuity }\end{array}$ & $\begin{array}{l}\text { IRA / } \\
\text { Keogh }\end{array}$ & $\begin{array}{l}\text { Corporate } \\
\text { Stock }\end{array}$ & $\begin{array}{l}\text { Mutual } \\
\text { Fund }\end{array}$ & $\begin{array}{l}\text { Tax Free } \\
\text { Assets }\end{array}$ \\
\hline $\begin{array}{l}\text { Variable } \\
\text { Annuity }\end{array}$ & 1.0 & 0.73 & 0.57 & 0.55 & 0.26 \\
\hline $\begin{array}{l}\text { IRA / } \\
\text { Keogh }\end{array}$ & 0.15 & 1.0 & 0.61 & 0.41 & 0.25 \\
\hline $\begin{array}{l}\text { Corporate } \\
\text { Stock }\end{array}$ & 0.12 & 0.76 & 1.0 & 0.54 & 0.42 \\
\hline $\begin{array}{l}\text { Mutual } \\
\text { Fund }\end{array}$ & 0.18 & 0.77 & 0.67 & 1.0 & 0.51 \\
\hline $\begin{array}{l}\text { Tax Free } \\
\text { Assets }\end{array}$ & 0.10 & 0.84 & 0.74 & 0.63 & 1.0 \\
\hline
\end{tabular}

Notes: Each entry shows the fraction of the asset indicated in the row that is held by households that also hold the asset in the column. Tax Free Assets include tax-exempt bond and money market funds as well as municipal bond funds. All entries are based on population-weighted tabulations from the 2001 Survey of Consumer Finances. 
Table 8: Probit Models for Ownership of Variable Annuities

\begin{tabular}{|c|c|c|c|c|}
\hline & \multicolumn{2}{|c|}{1998} & \multicolumn{2}{|c|}{2001} \\
\hline & Population-Weighted & Unweighted & Population-Weighted & Unweighted \\
\hline Net Worth Quintile 3 & $\begin{array}{c}0.0069 \\
(0.0065)\end{array}$ & $\begin{array}{c}0.0166 \\
(0.0163)\end{array}$ & $\begin{array}{c}0.0182 \\
(0.0102)\end{array}$ & $\begin{array}{c}0.0213 \\
(0.0160)\end{array}$ \\
\hline Net Worth Quintile 4 & $\begin{array}{c}0.0361 \\
(0.0137)\end{array}$ & $\begin{array}{c}0.0666 \\
(0.0260)\end{array}$ & $\begin{array}{c}0.0367 \\
(0.0140)\end{array}$ & $\begin{array}{c}0.0417 \\
(0.0202)\end{array}$ \\
\hline Net Worth Quintile 5 & $\begin{array}{c}0.0372 \\
(0.0158) \\
\end{array}$ & $\begin{array}{c}0.0551 \\
(0.0185) \\
\end{array}$ & $\begin{array}{c}0.0729 \\
(0.0239) \\
\end{array}$ & $\begin{array}{c}0.0645 \\
(0.0201) \\
\end{array}$ \\
\hline Income Quintile 2 & $\begin{array}{l}-.0072 \\
(.0032)\end{array}$ & $\begin{array}{l}-0.0154 \\
(0.0078)\end{array}$ & $\begin{array}{l}.0183 \\
(.0185)\end{array}$ & $\begin{array}{c}0.0262 \\
(0.0286)\end{array}$ \\
\hline Income Quintile 3 & $\begin{array}{l}-.0068 \\
(.0034\end{array}$ & $\begin{array}{l}-0.0073 \\
(0.0102)\end{array}$ & $\begin{array}{l}.0286 \\
(.0225)\end{array}$ & $\begin{array}{c}0.0327 \\
(0.0302)\end{array}$ \\
\hline Income Quintile 4 & $\begin{array}{l}-.0049 \\
(.0039)\end{array}$ & $\begin{array}{l}-0.0068 \\
(0.0104)\end{array}$ & $\begin{array}{l}.0282 \\
(.0243)\end{array}$ & $\begin{array}{c}0.0192 \\
(0.0256)\end{array}$ \\
\hline Income Quintile 5 & $\begin{array}{l}-.0067 \\
(.0039) \\
\end{array}$ & $\begin{array}{l}-0.0081 \\
(0.0126) \\
\end{array}$ & $\begin{array}{c}.0282 \\
(.0243) \\
\end{array}$ & $\begin{array}{c}0.0174 \\
(0.0202) \\
\end{array}$ \\
\hline Age $35-44$ & $\begin{array}{l}.0009 \\
(.0035)\end{array}$ & $\begin{array}{c}0.0018 \\
(0.0086) \\
\end{array}$ & $\begin{array}{l}-.0040 \\
(.0047) \\
\end{array}$ & $\begin{array}{c}0.0002 \\
(0.0087) \\
\end{array}$ \\
\hline Age $45-64$ & $\begin{array}{l}.0060 \\
(.0042)\end{array}$ & $\begin{array}{c}0.0156 \\
(0.0089) \\
\end{array}$ & $\begin{array}{l}.0035 \\
(.0049)\end{array}$ & $\begin{array}{c}0.0097 \\
(0.0084)\end{array}$ \\
\hline Age $>65$ & $\begin{array}{l}.0683 \\
(.0296) \\
\end{array}$ & $\begin{array}{c}0.0538 \\
(0.0249) \\
\end{array}$ & $\begin{array}{c}.0077 \\
(.0097) \\
\end{array}$ & $\begin{array}{l}-0.0008 \\
(0.0100) \\
\end{array}$ \\
\hline Education $=\mathrm{HS}$ & $\begin{array}{l}.0252 \\
(.0168) \\
\end{array}$ & $\begin{array}{c}0.0181 \\
(0.0182) \\
\end{array}$ & $\begin{array}{l}-.0094 \\
(.0052) \\
\end{array}$ & $\begin{array}{l}-0.0092 \\
(0.0087)\end{array}$ \\
\hline $\begin{array}{l}\text { Education }=\text { Some } \\
\text { College }\end{array}$ & $\begin{array}{l}.0231 \\
(.0168)\end{array}$ & $\begin{array}{c}0.0172 \\
(0.0181)\end{array}$ & $\begin{array}{l}-.0075 \\
(.0050)\end{array}$ & $\begin{array}{l}-0.0079 \\
(0.0087)\end{array}$ \\
\hline Education $=$ College & $\begin{array}{c}.0266 \\
(.0207) \\
\end{array}$ & $\begin{array}{c}0.0214 \\
(0.0193) \\
\end{array}$ & $\begin{array}{c}-.0022 \\
(.0059) \\
\end{array}$ & $\begin{array}{c}-0.0027 \\
(0.0096)\end{array}$ \\
\hline Education $>$ College & $\begin{array}{l}.0614 \\
(.0385)\end{array}$ & $\begin{array}{c}0.0370 \\
(0.0242)\end{array}$ & $\begin{array}{l}.0099 \\
(.0098)\end{array}$ & $\begin{array}{c}0.0057 \\
(0.0116)\end{array}$ \\
\hline $\mathrm{MTR} \approx 15 \%$ & $\begin{array}{l}.0137 \\
(.0077) \\
\end{array}$ & $\begin{array}{c}0.0248 \\
(0.0152) \\
\end{array}$ & $\begin{array}{l}-.0003 \\
(.0088) \\
\end{array}$ & $\begin{array}{l}-0.0104 \\
(0.0116) \\
\end{array}$ \\
\hline $\mathrm{MTR} \approx 28 \%$ & $\begin{array}{c}.0192 \\
(.0121) \\
\end{array}$ & $\begin{array}{c}0.0260 \\
(0.0172) \\
\end{array}$ & $\begin{array}{l}-.0035 \\
(.0086)\end{array}$ & $\begin{array}{c}0.0002 \\
(0.0116)\end{array}$ \\
\hline $\mathrm{MTR} \approx 32 \%$ & $\begin{array}{c}.0370 \\
(.0292)\end{array}$ & $\begin{array}{c}0.0497 \\
(0.0312)\end{array}$ & $\begin{array}{l}-.0013 \\
(.0096)\end{array}$ & $\begin{array}{c}0.0101 \\
(0.0169)\end{array}$ \\
\hline MTR $>35 \%$ & $\begin{array}{c}.0278 \\
(.0240)\end{array}$ & $\begin{array}{c}0.0269 \\
(0.0185)\end{array}$ & $\begin{array}{l}.0091 \\
(.0050)\end{array}$ & $\begin{array}{l}-0.0097 \\
(0.0094)\end{array}$ \\
\hline $\begin{array}{l}\text { Modest Risk } \\
\text { Aversion }\end{array}$ & $\begin{array}{l}-.0049 \\
(.0027)\end{array}$ & $\begin{array}{l}-0.0085 \\
(0.0058)\end{array}$ & $\begin{array}{l}-.0012 \\
(.0065)\end{array}$ & $\begin{array}{c}0.0020 \\
(0.0087)\end{array}$ \\
\hline More Risk Averse & $\begin{array}{l}-.0056 \\
(.0034) \\
\end{array}$ & $\begin{array}{l}-0.0100 \\
(0.0064) \\
\end{array}$ & $\begin{array}{l}-.0021 \\
(.0064) \\
\end{array}$ & $\begin{array}{c}0.0032 \\
(0.0084) \\
\end{array}$ \\
\hline Most Risk Averse & $\begin{array}{l}-.0151 \\
(.0046) \\
\end{array}$ & $\begin{array}{l}-0.0191 \\
(0.0065) \\
\end{array}$ & $\begin{array}{l}-.0068 \\
(.0066) \\
\end{array}$ & $\begin{array}{l}-0.0093 \\
(0.0088) \\
\end{array}$ \\
\hline Owns IRA/Keogh & $\begin{array}{l}-.0019 \\
(.0020)\end{array}$ & $\begin{array}{c}0.0050 \\
(0.0048)\end{array}$ & $\begin{array}{c}.0025 \\
(.0039) \\
\end{array}$ & $\begin{array}{c}0.0142 \\
(0.0058)\end{array}$ \\
\hline Has Pension & $\begin{array}{c}.0058 \\
(.0028) \\
\end{array}$ & $\begin{array}{c}0.0062 \\
(0.0043) \\
\end{array}$ & $\begin{array}{c}.0088 \\
(.0040) \\
\end{array}$ & $\begin{array}{c}0.0122 \\
(0.0047) \\
\end{array}$ \\
\hline Married & $\begin{array}{l}-.0034 \\
(.0028)\end{array}$ & $\begin{array}{l}-0.0024 \\
(0.0055)\end{array}$ & $\begin{array}{c}.0037 \\
(.0040)\end{array}$ & $\begin{array}{c}0.0079 \\
(0.0056)\end{array}$ \\
\hline Widow & $\begin{array}{l}-.0017 \\
(.0044)\end{array}$ & $\begin{array}{l}-0.0069 \\
(0.0087)\end{array}$ & $\begin{array}{c}.0438 \\
(.0222)\end{array}$ & $\begin{array}{c}0.0665 \\
(0.0308)\end{array}$ \\
\hline Has Children & $\begin{array}{c}.0029 \\
(.0024)\end{array}$ & $\begin{array}{c}0.0012 \\
(0.0044)\end{array}$ & $\begin{array}{l}-.0107 \\
(.0038)\end{array}$ & $\begin{array}{l}-0.0136 \\
(0.0048)\end{array}$ \\
\hline Sample Size & 3584 & 3584 & 3735 & 3735 \\
\hline
\end{tabular}

Source: Authors' estimates of probit models from 1998 and 2001 Surveys of Consumer Finances. See text for further details.

Reported estimates are probability derivatives rather than unadjusted coefficients. Standard errors are shown in parentheses. 


\section{RECENT WORKING PAPERS FROM THE \\ Center For Retirement Research at Boston College}

Living Arrangements and Supplemental Security Income Receipt Among the Aged Melissa M. Favreault and Douglas A. Wolf, February 2004

Interactions Between Social Security Reform and the Supplemental Security Income Program for the Aged

Paul S. Davies and Melissa M. Favreault, February 2004

Supply-Side Consequences of Social Security Reform: Impacts on Saving and Employment

Barry Bosworth and Gary Burtless, January 2004

It's All Relative: Understanding the Retirement Prospects of Baby-Boomers

Barbara A. Butrica, Howard M. Iams, and Karen E. Smith, November 2003

The Notional Defined Contribution Model: An Assessment of the Strengths and Limitations of a New Approach to the Provision of Old Age Security

John B. Williamson and Matthew Williams, October 2003

Simulating the Distributional Consequences of Personal Accounts: Sensitivity to Annuitization Options

Cori E. Uccello, Melissa M. Favreault, Karen E. Smith, and Lawrence H. Thompson, October 2003

Aggregate Implications of Defined Benefit and Defined Contribution Systems Francisco Gomes and Alexander Michaelides, September 2003

Can Unexpected Retirement Explain the Retirement-Consumption Puzzle? Evidence for Subjective Retirement Explanations Melvin Stephens Jr. and Steven J. Haider, August 2003

Employment, Social Security and Future Retirement Outcomes for Single Mothers Richard W. Johnson, Melissa M. Favreault, and Joshua H. Goldwyn, July 2003

The Outlook for Pension Contributions and Profits in the U.S. Alicia H. Munnell and Mauricio Soto, June 2003

Social Security Reform and the Exchange of Bequests for Elder Care Meta Brown, June 2003

All working papers are available on the Center for Retirement Research website (http://www.bc.edu/crr) and can be requested by e-mail (crr@bc.edu) or phone (617-552-1762). 